\title{
PRODUCTION REGIONS AND PHYSICAL QUALITY OF Urochloa decumbens CV. BASILISK SEEDS
}

\author{
REGIÕES DE PRODUÇÃO E QUALIDADE FÍSICA DE SEMENTES DE Urochloa \\ decumbens $C V$. BASILISK
}

\begin{abstract}
Givanildo Zildo da SILVA ${ }^{1}$; Cibele Chalita MARTINS ${ }^{2}$; José Oliveira CRUZ ${ }^{3}$; Tatiane Sanches JEROMINI ${ }^{3}$; Carla Gomes MACHADO ${ }^{1}$

1. Engenheiro Agrônomo, Professor, Pós-Doutorado, Universidade Federal de Goiás - UFG, Campus Jatobá, Jataí, GO, Brasil. givanildozildo@hotmail.com; 2. Engenheira Agrônoma, Professora Livre-Docente, Faculdade de Ciências Agrárias e Veterinárias UNESP, Jaboticabal, SP, Brasil; 3. Engenheiro Agrônomo, Mestrando, Faculdade de Ciências Agrárias e Veterinárias - UNESP, Jaboticabal, SP, Brasil; 4. Engenheira Agrônoma, Doutoranda, Faculdade de Ciências Agrárias e Veterinárias, Universidade Estadual Paulista - UNESP, Jaboticabal, SP, Brasil; 5. Engenheira Agrônoma, Professora, Doutora, Universidade Federal de Goiás - UFG, Campus Jatobá, Jataí, GO, Brasil.
\end{abstract}

\begin{abstract}
Brazil is the largest world producer, consumer and exporter of forage grass seeds. Urochloa decumbens Stapf. species is the second in importance in the Brazilian market of seeds of tropical forage grasses. Seeds are harvested by the soil sweeping method and, in addition to other impurities, harvested lots can present weed seeds, which makes seeds unfeasible for commercialization. The aim of the present study was to evaluate differences in the physical quality and viability of Urochloa decumbens cv. Basilisk seeds produced in different production fields. Fifteen U. decumbens seed lots from the State of São Paulo (1 lot in the municipality of Cássia dos Coqueiros and 3 lots in the municipality of Santo Antônio da Alegria), Minas Gerais ( 2 lots in the municipality of Tupaciguara, 2 lots in the municipality of Unaí, 2 lots in the municipality of Chapada Gaúcha and 3 lots in the municipality of Monte Santo de Minas), Goiás (1 lot in the municipality of Jataí) and Mato Grosso (1 lot in the municipality of Primavera do Leste) were evaluated by means of the following parameters: water content, viability by tetrazolium test, purity, determination of other seeds by number and weight of one thousand seeds. A completely randomized design was used, and when significant, the means of treatments were compared by the Scott Knott test at 5\% probability. The fields of the different regions produce $U$. decumbens seeds with high variability in physical quality. $U$. decumbens seeds with the highest physical quality and viability were produced in Cassia dos Coqueiros - SP.
\end{abstract}

KEYWORDS: Brachiaria decumbens. Physical purity. Weeds. Noxious seeds. Seed marketing.

\section{INTRODUÇÃO}

Brazil is the largest producer, consumer and exporter of forage seeds in the world (VIGNA et al., 2011). Among species, Urochloa decumbens Stapf., whose common name is decumbens, is the second in importance in the market of forage seeds and, although being the oldest planted species, continues to present high commercial demand for being rustic and easy to adapt in varied climatic and soil conditions (PEREIRA et al., 2011; CARDOSO et al., 2014). Despite its importance, Urochloa spp. still has poor physical quality and studies in this area are necessary (PEREIRA et al., 2011; CARDOSO et al., 2014).

The germination test is required for the commercialization of seeds of large crops. However, the marketing of Urochloa spp and Panicum maximum seeds can be carried out based on the viability results obtained through the tetrazolium test, supported by Normative Instruction 30/2010 / MAPA (BRASIL, 2008).

$U$. decumbens seeds are harvested by soil sweeping, and therefore, lots present large amounts of impurities, such as: empty spikelets, soil, sand, straw, stones, weed seeds, among others (MASCHIETTO et al., 2003; HESSEL et al. 2012; MELO et al., 2016ab; MELO et al., 2018). Weed seeds harvested along with seeds of the cultivated species may be classified as wild, noxious tolerant or noxious prohibited, and there is a maximum limit number of seeds per lot (BRASIL, 2009). When weed seeds are classified as noxious, they may make the marketing of seeds unfeasible (BRASIL, 2011; NERY et al., 2012).

The knowledge of weed seeds allows the creation of management techniques to inhibit or delay infestation and to avoid the propagation of propagules in seed production areas (CHRISTOFFOLETI et al., 2008). In these areas, there is competition of cultivated species with 
invasive plants for water, light, nutrients and $\mathrm{CO}_{2}$, affecting seed production and quality. In addition, weed seeds present competitive abilities and produce large quantities of viable seeds with high dispersion capacity (OLIVEIRA JUNIOR et al., 2011).

Some studies on the quality of forage seeds have verified differences in the physical quality of lots. Laura et al. (2009), in a study with $U$. brizantha, $U$. humidicola and $U$. decumbens seeds verified differences in the physical purity of six lots of each species in different locations in the region of Campo Grande - MS. However, in this work, the incidence of weed seeds was not evaluated. Thus, the present study aimed to evaluate differences in the physical quality of $U$. decumbens $\mathrm{cv}$. Basilisk seeds produced in different production fields.

\section{MATERIAL AND METHODS}

The work was carried out with $U$. decumbens seeds after mechanical harvesting of 15 second-year production fields in different municipalities and states of Brazil. The number of seeds lots obtained per production field and the geographic and climatic characteristics of the seed production regions are described in Table 1 .

Table 1. Localization, geographical coordinates, altitude and climate of 15 lots of Urochloa decumbens cv. Basilisk seeds from different production fields.

\begin{tabular}{|c|c|c|c|c|c|c|}
\hline \multirow{2}{*}{$\begin{array}{c}\text { Number of } \\
\text { lots }\end{array}$} & \multicolumn{2}{|r|}{ Production regions } & \multirow{2}{*}{ Latitude } & \multirow{2}{*}{ Longitude } & \multirow{2}{*}{ Altitude (m) } & \multirow{2}{*}{ Climate* } \\
\hline & State & City & & & & \\
\hline 1 & SP & Cássia dos Coqueiros & $21^{\circ} 16^{\prime} 58^{\prime \prime}$ & $47^{\circ} 10^{\prime} 11^{\prime \prime}$ & 918 & $\mathrm{Cfb}$ \\
\hline 3 & SP & Santo Antônio da Alegria & $21^{\circ} 05^{\prime} 13^{\prime \prime}$ & 4709’04” & 782 & $\mathrm{Cfa}$ \\
\hline 2 & MG & Tupaciguara & $18^{\circ} 35^{\prime} 32^{\prime \prime}$ & $48^{\circ} 42^{\prime} 18^{\prime \prime}$ & 896 & Aw \\
\hline 2 & MG & Unaí & $16^{\circ} 21^{\prime} 27^{\prime \prime}$ & $46^{\circ} 54^{\prime} 22^{\prime \prime}$ & 563 & Aw \\
\hline 2 & MG & Chapada Gaúcha & $15^{\circ} 18^{\prime} 20^{\prime \prime}$ & $45^{\circ} 37^{\prime} 06^{\prime \prime}$ & 871 & Aw \\
\hline 3 & MG & Monte Santo de Minas & $21^{\circ} 11^{\prime} 23^{\prime \prime}$ & $46^{\circ} 58^{\prime} 49^{\prime \prime}$ & 878 & Aw \\
\hline 1 & GO & Jataí & $17^{\circ} 52^{\prime} 53^{\prime \prime}$ & $51^{\circ} 42^{\prime} 52^{\prime \prime}$ & 732 & Aw \\
\hline 1 & MT & Primavera do Leste & $15^{\circ} 33^{\prime} 32^{\prime \prime}$ & $54^{\circ} 17^{\prime} 46^{\prime \prime}$ & 428 & Aw \\
\hline
\end{tabular}

* Classification according to Köppen and Geiger (1928). Cfa - Humid temperate climate with hot summer; Cfb - Humid temperate climate with moderate hot summer; Aw - Tropical savannah climate with dry winter season.

Seeds were harvested by the soil sweeping method. For this, plants were cut by a mower blade and arranged in line. The harvester swept the soil from the surface mixed with seeds to the inside, where this material was vented and sifted to remove part of impurities that were mixed with seeds.

Still in the field, the collected material composed of seeds and soil was pre-cleaned on a cylindrical sieve machine attached to the tractor power take-off. Subsequently, for each lot of crude seeds, $5 \mathrm{~kg}$ samples were obtained, which were homogenized, packed in paper packaging and sent to the Laboratory of Seed Analysis of the Department of Plant Production - Faculty of Agrarian and Veterinary Sciences of Jaboticabal Unesp, to determine the following parameters:

Water content - determined by the greenhouse method at $105 \pm 3^{\circ} \mathrm{C}$ for $24 \mathrm{~h}$ (BRASIL, 2009), with three subsamples of 0.5 grams of seeds

Viability by the tetrazolium test - four replicates of 50 seeds were pre-soaked on filter paper moistened with distilled water in the amount of 2.5 times the weight of the paper and kept in transparent plastic boxes with lid $(11.0 \times 11.0 \times 3.5$ $\mathrm{cm})$ at $25^{\circ} \mathrm{C}$ for 16 hours. They were then longitudinally sectioned through the embryo and endosperm, where one half was immersed in $0.1 \%$ tetrazolium solution at $30 \pm 3{ }^{\circ} \mathrm{C}$ for two hours in the absence of light (CARDOSO et al. 2014). Subsequently, seeds were washed in running water and the reading was performed, classifying seeds as viable and non-viable, according to Brasil (2009).

Physical purity - determined using three subsamples of $10.0 \mathrm{~g}$ of seeds weighed on a precision scale $(0.001 \mathrm{~g})$. The separation of components was carried out with sieves and pneumatic blower and the pure seed portion was obtained by manual separation, and the results were expressed as percentage of pure seeds, impurities and other seeds (BRASIL, 2009).

Determination of other seeds by number - in a sample of $100 \mathrm{~g}$ of seeds weighed on a precision scale $(0.001 \mathrm{~g})$ seeds of other species were counted and identified. In the impossibility of identification of the species, only the genus or botanical family of the other seeds was reported. The results were presented in number of seeds of each species by mass of sample (BRASIL, 2009). 
Weight of one thousand seeds - determined using eight subsamples of 100 seeds, collected from the pure seed portion and weighed on a precision scale $(0.001 \mathrm{~g})$, with results expressed in gram (BRASIL, 2009).

The experimental design was completely randomized. Data were tested for normality by the Shapiro-Wilk test, homoscedasticity by the Cochran test and submitted to ANOVA. For each parameter, data obtained were analyzed separately by analysis of variance and the means of treatments were compared by the Scott Knott test at 5\% probability.

\section{RESULTS AND DISCUSSION}

The water content of $U$. decumbens seeds from the 15 lots ranged from 8.5 to $10.5 \%$ (Table 2). The similarity in the water content values of seeds is essential for the quality analysis tests not to be affected by differences in metabolic activity, wetting rate and seed deterioration intensity (STEINER et al., 2011; MELO et al., 2016a; SILVA et al., 2017; MELO et al., 2018).

Table 2. Water content, viability by tetrazolium test, physical purity, inert material, other seeds and weight of one thousand seeds in the evaluation of the physical quality of 15 lots of Urochloa decumbens cv. Basilisk seeds from different production fields.

\begin{tabular}{|c|c|c|c|c|c|c|}
\hline \multirow[t]{2}{*}{ Lots } & $\begin{array}{l}\text { Water } \\
\text { content }\end{array}$ & $\begin{array}{l}\text { Viability } \\
\text { tetrazolium }\end{array}$ & $\begin{array}{l}\text { Physical } \\
\text { purity }\end{array}$ & $\begin{array}{c}\text { Inert } \\
\text { material }\end{array}$ & Other seeds & $\begin{array}{l}\text { Weight of } \\
\text { one } \\
\text { thousand } \\
\text { seeds }\end{array}$ \\
\hline & \multicolumn{5}{|c|}{ 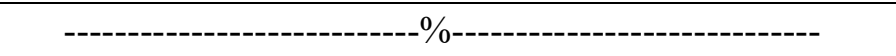 } & -----g----- \\
\hline Cássia dos Coqueiros - SP & 8,6 & $87 \mathrm{a}$ & $90,6 \mathrm{a}$ & $9,4 \mathrm{a}$ & $0,04 \mathrm{a}$ & $6,55 \mathrm{a}$ \\
\hline St. Antônio da Alegria - SP - Lot 1 & 8,8 & $83 \mathrm{~b}$ & $56,3 \mathrm{f}$ & $43,3 \mathrm{f}$ & $0,43 \mathrm{c}$ & $5,71 \mathrm{~d}$ \\
\hline St. Antônio da Alegria - SP - Lot 2 & 9,9 & $77 \mathrm{c}$ & $63,3 \mathrm{e}$ & 36,7 e & $0,01 \mathrm{a}$ & $5,10 \mathrm{~g}$ \\
\hline St. Antônio da Alegria - SP - Lot 3 & 9,4 & $80 \mathrm{c}$ & $67,0 \mathrm{~d}$ & $32,7 \mathrm{~d}$ & $0,26 \mathrm{~b}$ & $5,30 \mathrm{f}$ \\
\hline Chapada Gaúcha - MG - Lot 1 & 8,5 & $84 \mathrm{~b}$ & $55,8 \mathrm{f}$ & $44,1 \mathrm{f}$ & $0,08 \mathrm{a}$ & $5,10 \mathrm{~g}$ \\
\hline Chapada Gaúcha - MG - Lot 2 & 8,7 & $92 \mathrm{a}$ & $64,5 \mathrm{e}$ & $35,5 \mathrm{e}$ & $0,01 \mathrm{a}$ & $5,60 \mathrm{e}$ \\
\hline Monte St. de Minas - MG - Lot 1 & 9,7 & $86 \mathrm{~b}$ & $45,7 \mathrm{~g}$ & $54,3 \mathrm{~g}$ & $0,00 \mathrm{a}$ & $6,25 \mathrm{~b}$ \\
\hline Monte St. de Minas - MG - Lot 2 & 10,5 & $84 \mathrm{~b}$ & $42,3 \mathrm{~h}$ & $57,6 \mathrm{~h}$ & $0,07 \mathrm{a}$ & $5,96 \mathrm{c}$ \\
\hline Monte St. de Minas - MG - Lot 3 & 10,1 & $79 \mathrm{c}$ & $40,4 \mathrm{~h}$ & $59,6 \mathrm{~h}$ & $0,01 \mathrm{a}$ & $5,92 \mathrm{c}$ \\
\hline Tupaciguara - MG - Lot 1 & 9,0 & $90 \mathrm{a}$ & $81,6 \mathrm{~b}$ & $18,2 \mathrm{~b}$ & $0,21 \mathrm{~b}$ & $6,17 \mathrm{~b}$ \\
\hline Tupaciguara - MG - Lot 2 & 8,9 & $89 \mathrm{a}$ & $77,3 \mathrm{c}$ & $22,2 \mathrm{c}$ & $0,49 \mathrm{c}$ & $5,34 \mathrm{f}$ \\
\hline Unaí - MG - Lot 1 & 9,2 & $84 \mathrm{~b}$ & $77,0 \mathrm{c}$ & $23,0 \mathrm{c}$ & $0,00 \mathrm{a}$ & $5,41 \mathrm{f}$ \\
\hline Unaí - MG - Lot 2 & 9,0 & $85 \mathrm{~b}$ & $77,3 \mathrm{c}$ & $22,7 \mathrm{c}$ & $0,06 \mathrm{a}$ & $5,10 \mathrm{~g}$ \\
\hline Jataí - GO & 9,4 & $85 \mathrm{~b}$ & $87,2 \mathrm{a}$ & $12,8 \mathrm{a}$ & $0,01 \mathrm{a}$ & $4,98 \mathrm{~g}$ \\
\hline Primavera do Leste $-\mathrm{MT}$ & 9,5 & $79 \mathrm{c}$ & $75,0 \mathrm{c}$ & $24,9 \mathrm{c}$ & $0,16 \mathrm{a}$ & $5,03 \mathrm{~g}$ \\
\hline $\bar{F}$ & - & $75,5^{* *}$ & $129,5^{* *}$ & $127,8^{* *}$ & $9,9^{* *}$ & $126,0^{* *}$ \\
\hline Coefficient of variation $(\%)$ & - & 3,7 & 3,7 & 7,4 & 71,2 & 2,3 \\
\hline
\end{tabular}

According to the results of the tetrazolium test, seed viability ranged from 77 to $92 \%$. Seeds from Cassia dos Coqueiros - SP, lots 1 and 2 from Tupaciguara - MG and lot 2 from Chapada Gaúcha MG, stood out compared to the others regarding viability evaluated by the tetrazolium test, with values between 87 and $92 \%$ of viable seeds. It was verified that the lowest percentage of viable seeds was verified in lots 2 and 3 produced in Santo Antônio da Alegria - SP, lot 3 from Monte Santo de
Minas - MG and Primavera do Leste - MT, with values of $77,80,79$ and $79 \%$, respectively.

The percentages of viable seeds detected in the 15 lots of $U$. decumbens seeds were similar to those found in other seedlings of this genus (CUSTÓDIO et al., 2012; QUADROS et al. 2012; CARDOSO et al., 2014; PEREIRA et al., 2014). Quadros et al. (2012) considered that the average of $68.4 \%$ of seed viability was satisfactory for $U$. 
brizantha seeds of Marandú and Xaráes cultivars; thus, verifying the high viability of evaluated lots.

The physical purity of seeds from different $U$. decumbens production fields was between 40.4 and $90.6 \%$. Approximately $33 \%$ of production fields presented seed lots with values below standards established by the Ministry of Agriculture for commercialization (BRASIL, 2008), since they had purity between 40.4 and $56.3 \%$. Thus, based on the purity characteristics alone, most lots of crude seeds, even without beneficiation, could be commercialized in the national market, since the minimum purity required by standards for production and commercialization of forage seeds for Brachiaria is $60 \%$ (BRASIL, 2008).

Considering the purity percentage and inert material content in seeds from different production fields, the following classification was verified: seeds from Cássia dos Coqueiros - SP, lot1 Tupaciguara - MG and Jataí - GO as high quality (purity superior to $80 \%$ and, consequently, inert material content lower than 20\%); lots 2 and 3 from Santo Antônio da Alegria - SP, lot 2 from Tupaciguara - MG, lot 2 from Chapada Gaúcha MG, lots 1 and 2 from Unaí - MG and Primavera do Leste - MT of intermediate-high quality (purity between 60 and $80 \%$ ). These fields produced seeds with purity values above requirements for commercialization.

Lots 1 from Santo Antônio da Alegria - SP and lot 1 from Chapada Gaúcha - MG produced seeds classified as intermediate-low quality (purity between 50 and $60 \%$ ); the three lots produced in Monte Santo de Minas - MG were classified as low quality (50\% less purity). These lots would need processing to meet requirements for commercialization.

The physical quality of crude seeds, recently harvested in the field, is usually related to the conduction of the production field and to the methods and procedures used in harvest (LIMA JUNIOR et al., 2015). Therefore, the purity results obtained in the work may be related to non-climatic factors, such as field management and differences in adjustments in the harvesting and pre-cleaning machines.

Harvest methods and harvester settings can affect the physical quality of seeds due to the management used by each producer (MASCHIETTO, 2013). The most widely used method of harvesting $U$. brizantha seeds is by mechanized soil sweeping (QUADROS et al., 2012). However, no studies on the effect of the adjustment of this type of harvesters on the quality of forage seeds were found.

In the 15 lots evaluated, the predominant impurities were straws, stones, clods, weed seeds, immature seeds, and those deteriorated and severely attacked by fungi so that the species could not be identified. This type of impurities was also identified in the crude seeds of works on the processing of Mombasa-grass (MELO et al., 2016a), Tanzania-grass (MELO et al., 2016b), Brachiara (HESSEL et al., 2012) and Massai-grass seeds (MELO et al., 2018).

Regarding the other seeds, weeds predominated. The highest percentages of these seeds $(0.43$ and $0.49 \%)$ were found in lot 1 from Santo Antônio da Alegria and lot 2 from Tupaciguara - MG, respectively, followed by lot 3 from Santo Antônio da Alegria - SP and lot 1 from Tupaciguara - MG (0.26 and 0.21\%). Possibly, in these fields, weed control had failed. This fact shows the importance of field surveys during the vegetative period for weed control, as prescribed by Seed Standards (BRASIL, 2008).

After harvesting, the similarity between weed and forage seeds in terms of size, weight and shape may make it unfeasible to separate them by processing (MASCHIETTO, 2013).

For the weight of one thousand seeds, it was verified that the lot produced in Cássia dos Coqueiros - SP, obtained the largest weight ( $6.55 \mathrm{~g})$, followed by lots 1 from Tupaciguara - SP and 1 from Monte Santo de Minas - SP 6.25 and $6.17 \mathrm{~g}$ ). Lots 2 from Santo Antonio da Alegria - SP, 1 from Chapada Gaúcha - MG, 2 from Unaí - SP, Jataí GO and Primavera do Leste - MT presented the lowest weights of one thousand seeds.

In the determination of other seeds by number, the presence of seeds of 17 weed species (Figure 1) was verified: lot from Cássia dos Coqueiros - SP (1 Plantago lanceolata seed and 1 Polygonum convolvulus seed, lot 1 from Santo Antônio da Alegria - SP (421 Acanthospermum hispidum seeds, 2 Acanthospermum australe seeds, 1 Commelina benghalensis seed, 7 Crotalaria incana seeds, 1 Croton glandulosus seed, 4 Sida rhombifolia seeds, 1 Sida cordifolia seed, 2 Panicum miliaceum seeds and 1 Plantago lanceolata seed), lot 2 from Santo Antônio da Alegria - SP (1 Plantago lanceolata seed) and lot 3 from Santo Antônio da Alegria - SP (1 Croton glandulosus seed, 14 Ipomea spp seeds, 11 Leucaena leucocephala seeds, 3 Senna obtusifoli seeds and 1 Sida rhombifolia seed). 


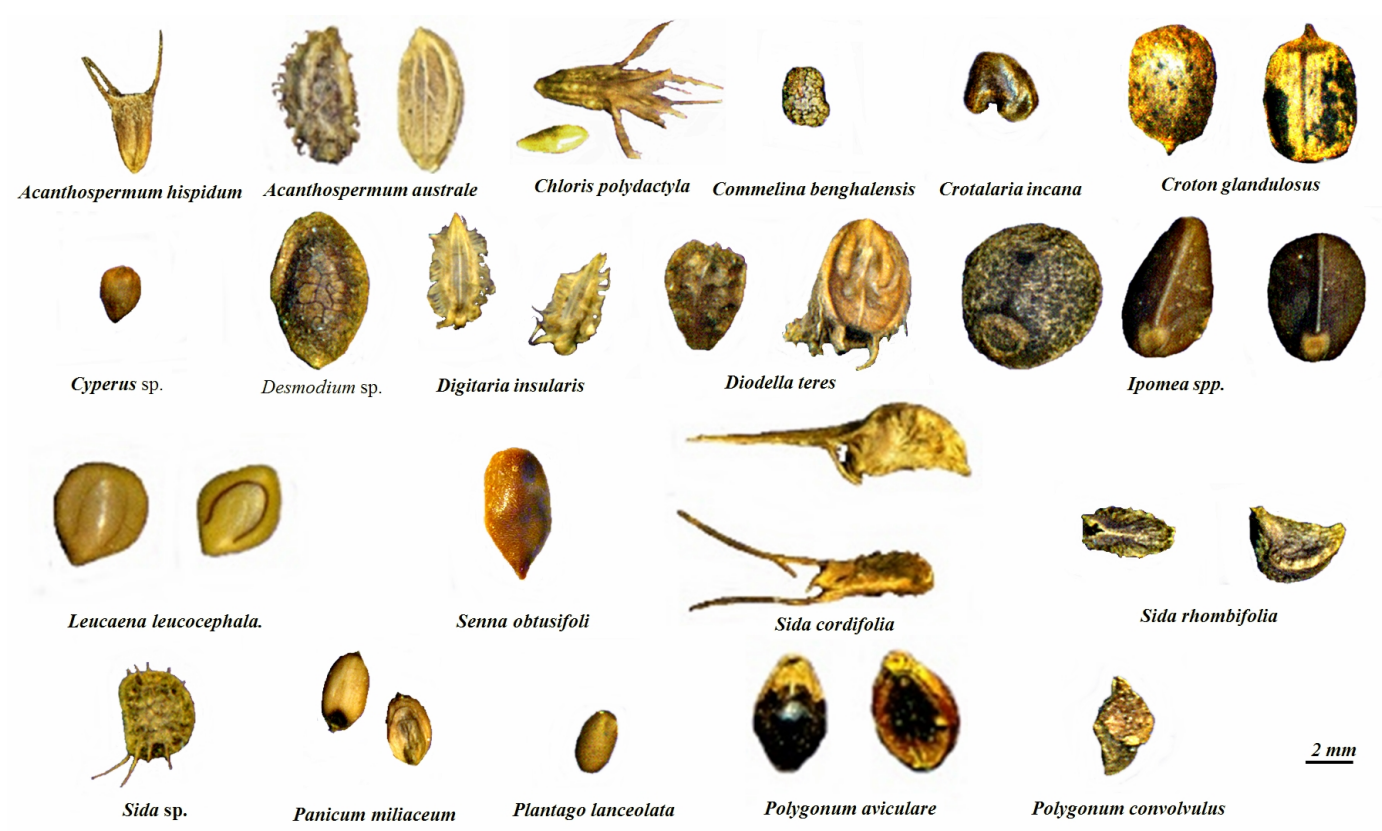

Figure 1. Seeds of weed species found in the evaluation of other seeds by number in 15 Urochloa decumbens $\mathrm{cv}$. Basilisk seed lots from different production fields.

Seeds of weeds present in lots from the State of Minas Gerais: lot 1 from Tupaciguara (3 Croton glandulosus seeds, 1 Crotalaria incana seed, 15 Leucaena leucocephala seeds and 1 Panicum miliaceum seed), lot 2 from Tupaciguara (64 Acanthospermum australe seeds, 2 Croton glandulosus seeds, 1 Crotalaria incana seed, 4 Digitaria insularis seeds, 121 Diodella teres seeds, 6 Sida cordifolia seeds, 2 Sida rhombifolia seeds and 1 Plantago lanceolata seed), lot 1 from Unaí (1 Panicum miliaceum seed), lot 2 from Unaí (3 Panicum miliaceum seeds), lot 2 from Monte Santo Antônio da Alegria (1 Acanthospermum australe seed, 2 Crotalaria incana seeds, 10 Diodella tere seeds, 4 Sida rhombifolia seeds and 2 Polygonum aviculare seeds) and lot 3 from Monte Santo Antônio da Alegria (2 Acanthospermum australe seeds).

Seed lot from Jataí - GO showed seeds of four weed species (1 Acanthospermum australe seed, 6 Croton glandulosus seeds, 39 Digitaria insularis seeds, 2 Sida cordifolia seeds and 1 Panicum miliaceum seed).

For the seed lot harvested in Primavera do Leste - MT, seeds of eight weed species was found (1 Acanthospermum australe seed, 17 Croton glandulosus seeds, 15 Diodella tere seeds, 10 Sida sp. seeds, 4 Sida cordifolia seeds, 2 Sida rhombifolia seeds, 1 Panicum miliaceum seed and 1 Plantago lanceolata seed).

In the municipalities of Chapada Gaúcha MG and lot 1 from Monte Santo de Minas - MG, the presence of weed seeds was not verified. It was not possible to attribute the higher incidence of seeds of these weeds to the climatic factors of producing regions, since they are cosmopolitan invasive plants, which are distributed throughout the Southern, Southeastern and Midwestern states (LORENZI, 2014).

In the different evaluated lots, the presence of weed seeds classified by Brasil (2008) as noxious prohibited was not verified. However, there was a high incidence of wild and noxious tolerated invasive plant seeds. In this way, the seed lot from Jataí - GO would be rejected for commercialization for presenting 39 Digitaria insularis seeds, noxious tolerated up to 31 seeds per evaluated sample (BRASIL, 2008). As well as lot 2 from Tupaciguara for presenting 121 Diodella teres seeds, noxious tolerated up to 20 seeds per evaluated sample (BRASIL, 2008).

For presenting number of wild invasive plant seeds greater than 30 per 100 grams of sample evaluated (BRASIL, 2008; BRASIL, 2009) lot 2 from Santo Antônio da Alegria - SP, lot 2 from Tupaciguara - MG and lot from Primavera do Leste - MT would also be rejected for commercialization because they presented 432, 67 and 35 wild invasive plant seeds, respectively.

In the other lots, only seeds of noxious tolerated weeds, such as Ipomoea spp., Sida spp. and Polygonum spp were recorded, but below the number prescribed by Seed Standards (BRASIL, 2008). Therefore, these lots could be marketed. In addition, crude seeds would also be submitted to the beneficiation process, which is able to remove all or 
part of weed seeds (CARVALHO; NAGAKAWA, 2012; MELO et al., 2016ab; MELO et al., 2018). Thus, the results of this work characterize the need for a better monitoring of decumbens seed production fields in the weed control.

As for the weight of one thousand seeds (Table 2), those from Cássia dos Coqueiros - SP presented the highest values of $6.55 \mathrm{~g}$. The improved pre-cleaning carried out in the production field increased the purity of the lot, but lighter seeds should also have removed from the lot. According to information provided by the Marangatú Seeds ${ }^{\circledR}$ Company, producers from Cássia dos Coqueiros SP have stood out from the others over the years due to the higher quality of seeds they produce. This type of production would be ideal, since they always try to produce the best seeds and not only seeds within the required standards (TOLEDO, 1977).
In addition to improved pre-cleaning, the Cássia dos Coqueiros-SP region should favor seed filling, as the favorable climatic conditions of production regions, harvesting season and plant nutrition may increase seed mass. In contrast, seeds from Jataí - GO had the lowest weight of one thousand seeds, of $4.98 \mathrm{~g}$. The influence of climatic conditions on the weight of one thousand seeds was reported by Laura et al. (2009), for $U$. decumbens, $U$. brizantha and $U$. humidicola.

\section{CONCLUSIONS}

The fields of the different regions produced $U$. decumbens seeds with great variability in physical quality.

$U$. decumbens seeds with higher physical quality and viability were produced in Cassia dos Coqueiros - SP.

RESUMO: O Brasil é o maior produtor, consumidor e exportador de sementes de forrageiras no mundo. A espécie Urochloa decumbens Stapf. é a segunda em importância no mercado brasileiro de sementes de gramíneas forrageiras tropicais. A colheita das sementes ocorre pelo método de varredura do solo e, além de outras impurezas, podem apresentar sementes de plantas daninhas que podem inviabilizar a comercialização de lotes de sementes. A presente pesquisa teve como objetivo avaliar diferenças na qualidade física e viabilidade de sementes de Urochloa decumbens cv. Basilisk produzidas em diferentes campos de produção. Foram avaliados 15 lotes de sementes de $U$. decumbens, procedentes dos Estados de São Paulo (1 lote do município de Cássia dos Coqueiros e 3 lotes do município de Santo Antônio da Alegria), Minas Gerais (2 lotes do município de Tupaciguara, 2 lotes do município de Unaí, 2 lotes do município de Chapada Gaúcha e 3 lotes do município de Monte Santo de Minas), Goiás (1 lote do município de Jataí) e Mato Grosso (1 lote do município de Primavera do Leste); por meio dos seguintes parâmetros: teor de água, viabilidade pelo teste de tetrazólio, pureza, determinação de outras sementes por número e massa de mil sementes. Adotou-se o delineamento inteiramente casualizado e as médias dos tratamentos foram comparadas pelo teste de Scott Knott, a 5\% de probabilidade. Os campos das diferentes regiões produzem sementes de $U$. decumbens com alta variabilidade na qualidade física. As sementes de $U$. decumbens com maior qualidade física e viabilidade foram produzidas em Cassia dos coqueiros - SP.

PALAVRAS-CHAVE: Brachiaria decumbens. Pureza física. Plantas daninhas. Sementes plantas nocivas. Comercialização de sementes.

\section{REFERENCES}

BRASIL. Ministério da Agricultura, Pecuária e Abastecimento. Guia de inspeção de campos para produção de sementes. 3. Ed. Brasília: Mapa/ACS, 2011.41 p.

BRASIL. Ministério da Agricultura, Pecuária e Abastecimento. Regras para análise de sementes. Brasília: MAPA/ACS, 2009. 399 p.

BRASIL. Ministério da Agricultura, Pecuária e do Abastecimento Gabinete do Ministro. Instrução Normativa $\mathrm{n}^{\circ}$ 30, de 21 de maio de 2008. Publicado no Diário Oficial da União, Poder Executivo, 23 de maio de 2008, Seção 1, p. 45. 
CARDOSO, E. D.; SÁ, M. E.; HAGA, K. I.; BINOTTI, F. F. S.; NOGUEIRA, D. C.; VALERIO FILHO, W. V. Desempenho fisiológico e superação de dormência em sementes de Brachiaria brizantha submetidas a tratamento químico e envelhecimento artificial. Semina Ciências Agrárias, Londrina, v. 35, n. 1, p. 21-38, 2014. http://dx.doi.org/10.5433/1679-0359.2014v35n1p21.

CARVALHO, N. M.; NAKAGAWA, J. Sementes: ciência, tecnologia e produção. Jaboticabal: FUNEP, 2012. $590 \mathrm{p}$.

CHRISTOFFOLETI, P. J.; OVEJERO, R. F. L.; NICOLAI, M.; VARGAS, L.; CARVALHO, S. J. P.; CATANEO, A. C.; CARVALHO, J. C.; MOREIRA, M. S. Aspectos de resistência de plantas daninhas a herbicidas. Piracicaba, Associação Brasileira de Ação a Resistencia de Plantas aos Herbicidas, 2008. 120 p.

CUSTÓDIO, C. C.; DAMASCENO, R. L.; MACHADO NETO; N. B. Imagens digitalizadas na interpretação do teste de tetrazólio em sementes de Brachiaria brizantha. Revista Brasileira de Sementes, Londrina, v. 34, n. 2, p. 334-341, 2012. http://dx.doi.org/10.1590/S0101-31222012000200020.

HESSEL, C. L. E.; VILLELA, F. A.; AUMONDE, T. Z.; PEDÓ, T. Mesa densimétrica e qualidade fisiológica de sementes de brachiária. Informativo ABRATES, Londrina, v. 22, n. 3, p. 73-76, 2012.

KÖPPEN, W.; GEIGER, R. Klimate der Erde. Gotha: Verlag Justus Perthes. 1928. (Wall-map $150 \mathrm{~cm} 200 \mathrm{~cm})$.

LAURA, V. A.; RODRIGUES, A. P. D. C.; ARIAS, E. R. A.; CHERMOUTH, K. S.; ROSSI, T. Qualidade física e fisiológica de sementes de braquiárias comercializadas em Campo Grande - MS. Ciência e Agrotecnologia, Lavras, v. 33, n. 1, p. 326-332, 2009. http://doi.org/10.1590/S1413-70542009000100045.

LIMA JUNIOR, M. J. V.; MARTINS, C. C.; GROTH, D.; LOPES, M. T. G. Amostragem e pureza de sementes florestais. In: PIÑA-RODRIGUES, F. C. M.; FIGLIOLIA, M. B.; SILVA, A. Sementes florestais tropicais: da ecologia à produção. $1^{\mathrm{a}}$ ed. Londrina: ABRATES, 2015, v. 1, p. 289-307.

LORENZI, H. Manual de identificação e controle de plantas daninhas. 7 ed. São Paulo: Instituto Plantarum, 2014. 384 p.

MASCHIETTO, J. C.; O "rally" da fiscalização de campo. Revista JC Maschietto, n. 11, 2013. Disponível em: http://www.jcmaschietto.com.br/index.php?link=artigos\&sublink=artigo_85. Acesso em: 13 mar. 2018.

MASCHIETTO, R. W.; NOVEMBRE, A. D. L. C.; SILVA, W. R. Métodos de colheita e qualidade das sementes de capim colonião cultivar Mombaça. Bragantia, Campinas, v. 62, n. 2, p. 291-296, 2003. http://dx.doi.org/10.1590/S0006-87052003000200015.

MELO, L. F.; MARTINS, C. C.; SILVA, G. Z.; BONETI, J. E. B.; VIEIRA, R. D. Beneficiamento na qualidade física e fisiológica de sementes de capim-mombaça. Revista Ciência Agronômica, Fortaleza, v. 47, n. 4, p. 667-674, 2016a. http://doi.org/10.5935/1806-6690.20160080.

MELO, L. F.; MARTINS, C. C.; SILVA, G. Z.; PEREIRA, F. E. C. B.; JEROMINI, T. S. Effects of processing phases on the quality of massai grass seeds. Revista Ciência Agronômica, Fortaleza, v. 49, n. 2, p. 259-266, 2018. http://dx.doi.org/10.5935/1806-6690.20180029.

MELO, L. F.; MARTINS, C. C.; SILVA, G. Z.; SANCHES, M. F. G. Processing in the quality of tanzania grass seeds. Engenharia Agrícola, Jaboticabal, v. 36, n. 6, p. 1157-1166, 2016 b.

http://dx.doi.org/10.1590/1809-4430-eng.agric.v36n6p1157-1166/2016.

NERY, M. C.; NERY, F. C.; SILVA, D. R. G.; SOARES, F. P. Produção de sementes forrageiras. Boletim Técnico, UFLA, Lavras, n. ${ }^{\circ} 88$, p. 1-47, 2012. 
OLIVEIRA JUNIOR, R. S.; CONSTANTIN, J.; INOUE, M. H. Biologia e manejo de plantas daninhas. Curitiba: Editora OMNIPAX, 2011. 348 p.

PEREIRA, A. M.; ABRANTES, F. L.; MACHADO-NETO, N. B.; CUSTÓDIO, C. C. Ar seco e aquecido no processo de dormência e germinação de sementes de Urochloa humidicola. Colloquium Agrariae, Presidente Prudente, v. 10, n.1, p. 09-25, 2014. http://doi.org/10.5747/ca.2014.v10.n1.a096.

PEREIRA, C. E.; OLIVEIRA, J. A.; ROSA, M. C. M.; KIKUTI, A. L. P. Armazenamento de sementes de braquiária peletizadas e tratadas com fungicida e inseticida. Ciência Rural, Santa Maria, v. 41, n. 12, p. 2060 2065, 2011. http://dx.doi.org/10.1590/S0103-84782011001200004.

QUADROS, D. G.; ANDRADE, A. P.; OLIVEIRA, G. C.; OLIVEIRA, E. P.; MOSCON, E. S. Componentes da produção e qualidade de sementes dos cultivares Marandú e Xaraés de Brachiaria brizantha (Hochst. ex A. Rich.) Stapf colhidas por varredura manual ou mecanizada. Semina Ciências Agrárias, Londrina, v. 33, n. 5, p. 2019-2028, 2012. http://doi.org/10.5433/1679-0359.2012v33n5p2019.

SILVA, G. Z.; MARTINS, C. C.; CRUZ, J. O.; JEROMINI, T. S.; BRUNO, R. L. A. Evaluation the physiological quality of Brachiaria brizantha cv. BRS 'Piatã' seeds. Bioscience Journal, Uberlândia, v. 33, n. 3, p. 572-580, 2017. http://dx.doi.org/10.14393/BJ-v33n3-36519.

STEINER, F.; OLIVEIRA, S. S. C.; MARTINS, C. C.; CRUZ, S. J. S. Comparação entre métodos para a avaliação do vigor de lotes de sementes de triticale. Ciência Rural, Santa Maria, v. 41, n. 2, p. 200-204, 2011. http://dx.doi.org/10.1590/S0103-84782011005000011.

TOLEDO, F. F. Manual das sementes: tecnologia da produção. São Paulo: Agronômica Ceres, 1977. 224 p.

VIGNA, B. B. Z.; JUNGMANN, L.; FRANCISCO, P. M.; ZUCCHI, M. I.; VALLE, C. B.; SOUZA, A. P. Genetic Diversity and Population Structure of the Brachiaria brizantha Germplasm. Tropical Plant Biology, v. 4, n. 3-4, p. 157-169, 2011. http://dx.doi.org/10.1007/s12042-011-9078-1. 